\title{
Kulturális metaforák és sémák a magyar népdalok FOLYó-reprezentációiban*
}

\author{
1. rész
}

\section{Bevezetés}

1.1. A dolgozat célja. A népdalok számuk és nagyfokú változatosságuk okán a magyar népköltészet központi kategóriáját képezik. Szövegtipológiai szempontból érdekességük, hogy míg egyfelől a hagyományos népi (paraszti) közösségek kollektív alkotásai, addig másfelől lírai üzenetet, személyes érzelmeket jelenítenek meg, amelynek fontos eszköze a metaforikus reprezentáció. A népdalok nagy hányada valamilyen természeti jelenetben (vö. természeti kezdőkép, MNL. 5: 271), természeti tárgyakban és jelenségekben, indirekt módon közvetíti a személyes érzelmeket. A természeti jelenetek jelentéstartalma a népi közösségen kívülálló szemlélő számára gyakran homályos, és a bennük kifejeződő metaforák és sémák konceptuális elemzésére még igen kevés nyelvészeti kísérlet történt (BARANYINÉ KÓCZY 2010, 2014, 2016, 2018; 1. még SZELID 2007 vizsgálatait a csángó népdalok szerelmi metaforáiról). A tanulmány elméleti keretét adó kulturális nyelvészeti megközelítésben a népdalok a hagyományos paraszti közösségek világnézetének hordozói, hiszen ebben a kontextusban születtek és alakultak az idők folyamán, valamint a népi megismerés kulturáli s k o n c e p t u a li zá c i ó i t (cultural conceptualizations) reprezentálják.

A tanulmány célja a szerelmi kontextusban megjelenő FOLYÓ-reprezentációkhoz kapcsolódó metaforák és képi sémák vizsgálata. Ennek során a következő állításokat fogalmazom meg: a) a vizsgált korpuszban (ORTUTAY-KATONA szerk. 1975) a FOLYÓ-reprezentációk egy alapvető kulturális metaforára, AZ ÉRZELEM FOLYÓVÍZ metaforára vezethetők vissza, azt dolgozzák ki; b) a FOLYÓ-metaforák csak részben értelmezhetők generikus(abb) szintű fogalmi metaforák segítségével, mivel jelentős mértékben kultúraspecifikus tapasztalatokban gyökereznek; c) általánosságban véve a metaforák az ún. SZEMÉRMESSÉG kulturális sémán keresztül fejeznek ki érzelmeket, amely a paraszti kultúrában elterjedt erkölcsi normákból és a házasság szokásrendszeréből ered.

1.2. A kulturális konceptualizációk fogalma. Az elmúlt években mind a hazai, mind pedig a nemzetközi nyelvtudományi kutatásokban egyre határozottabban megjelent az a felismerés, hogy a nyelv, a megismerés és a kultúra, beleértve a metaforikus gondolkodást és kifejezésmódot, szorosan összefüggnek (KöVECSES 2000, 2005a, 2005b; SHARIFIAN 2011, 2017; YU 2003). Ebben a kontextusban a kultúrát gyakorlati, elsősorban nyelvészeti szempontból alkalmazva „akkor be-

* A tanulmány az EFOP-3.6.1-16-2016-00017 számú Nemzetköziesítés, oktatói, kutatói és hallgatói utánpótlás megteremtése, a tudás és technológiai transzfer fejlesztése mint az intelligens szakosodás eszközei a Széchenyi István Egyetemen címü pályázat támogatásával készült. 
szélhetünk kultúráról, ha valamely adott társadalmi, történelmi és fizikai környezetben élö embercsoport többé-kevésbé egységes módon értelmezi azt, amit átél" (KÖVECSES 2012: 17; vö. STRAUSS-QUINN 1998).

A metaforák kultúrák közötti eltérése a kulturális nyelvészet egyik központi kutatási területévé vált (pl. SHARIFIAN 2017; YU 2017), amely több tudományterület eszköztárát integrálja, így többek között a kognitív nyelvészet és az antropológiai nyelvészet módszereit. A kulturális nyelvészet arra mutat rá, hogy a $\mathrm{k} \mathrm{u} 1$ turális metaforák olyan kulturális konceptualizációkként (cultural conceptualizations) értelmezendők, amelyek a kulturális megis m e ré s b e n (cultural cognition), a kulturális közösségek tagjai között megosztott reprezentációk hálózatában gyökereznek (SHARIFIAN 2011: 5).

Egy közösséget jellemző implicit fogalmi rendszer egy adott csoport ismereteit és vélekedéseit tartalmazza az életről, a világmindenségről, a vallásról, a környezetről, az érzelmekröl stb. (SHARIFIAN 2015: 477), amelyet a tagjai az egymással folytatott interakciók során folyamatosan alakítanak, és amely az egyedek között heterogén módon, a családi hasonlóság elve szerint oszlik meg (RosCHMERVIS 1975). Ez a meglátás a szociológiában és a folklórkutatásban már régóta jelen van: ,,amit az emberek tudnak a mindennapok valóságáról, az egy olyan köztudat (= közös tudás), amely mindent jelentéssel lát el, és amely nélkül egyetlen társadalom sem létezhet" (BERGER-LUCKMAN 1967: 27, idézi HOPPÁL 1982: 331). A kulturális konceptualizációk a közösségre jellemző fogalmi rendszer közvetítői a nyelvben a kulturális sémák, kategóriák és metaforák megvalósulási formáiban. Ennek megfelelően a népdalok metaforái olyan kulturális konceptualizációk, amelyek az emberi életre vonatkozó kollektív tapasztalatokból (mint céltartomány) és a természeti környezet percepcióiból (mint forrástartomány) erednek, a magyar népi közösségekre jellemző módon formálva át őket. Ezek a kulturális metaforák és sémák így nemcsak arról tanúskodnak, hogy a csoportok tagjai miként alakítják a tapasztalataikat metaforikus konceptualizációkká, hanem arról is, hogyan vélekednek az érzelmekről és a természetről általában, milyen értékeket tulajdonítanak a természeti tárgyaknak és jelenségeknek, esetünkben a folyóknak (vö. pl. IDSTRÖM 2012; SHARIFIAN et al. 2008; YU 2007).

A kulturális metaforák átfedéseket mutatnak a fogalmi metaforaelméletben leírt metaforákkal (LAKOFF - JOHNSON 1980), de számos szempontból speciális csoportot képeznek, és egyes jellemzőikben el is térhetnek tőlük. A kultúrák közötti eltérések legfőbb okai KöVECSES (2005a) szerint a forrás- és a céltartományok kiválasztásának módja, a megfeleltetések kialakítása, valamint egy generikus séma kultúránként eltérő specifikus megjelenítése. A metaforák fogalmi szerkezeti különbségeiben fontos szerepet játszik az, hogy eltérő tapasztalatokon alapulnak, mind a fizikai környezetre, a társadalmi vagy a szituációs kontextusra vonatkozólag, továbbá a kognitív preferenciák is mások az egyes közösségekben. Azonban mindkét folyamatot kulturális tényezők alakítják (KöVECSES 2005a: 232, 246).

A kulturális metaforák olyan fogalmi metaforák, amelyek egy kulturális közösséget jellemeznek, és a következő tulajdonságokkal rendelkeznek (1. részletesen BARANYINÉ KÓCZY é. n.). Gyakran kulturális kategóriákon alapulnak, vagyis 
olyan kategóriákon, amelyek a közösségre jellemzők, s amelyek a megismerésben központi szerepet töltenek be (YU 2017). A kulturális sémák szintén meghatározóak a kulturális metaforák kialakulásában és értelmezésében. A kulturális sémák a kognitív sémák, forgatókönyvek kulturálisan megszerkesztett megfelelöi: kollektív szabályokat, vélekedéseket, várakozásokat, attitüdöket jelenítenek meg; gyakoribb típusai az eseménysémák, a szerepsémák, az érzelemsémák és a képi sémák (SHARIFIAN 2011: 8-11; POLZENHAGEN-FrEY 2017). A kulturális metaforák jelentése gyakran alapvető kulturális sémákkal magyarázhatók. A népdalok továbbá szorosan kapcsolódhatnak képi sé mákhoz (képi-sematikus jelentésstruktúrákhoz). A képi séma ,az ember cselekvésein, észlelésein és fogalmain alapuló minta, amely főképp az emberi test térben mozgásából vagy a tárgymanipulációból ered" (TOLCSVAI NAGY 2013: 80; JOHNSON 1987). A képi sémák mint „azonnal felidézhető ikonikus képek” szociokulturális tapasztalati alapját hangsúlyozza PALMER (1996: 66). Továbbá, a kulturális metaforák gyakran több különböző generikusabb szintü metaforára vezethetők vissza, ami a forrástartományhoz kapcsolódó kulturális tapasztalatot meghatározó voltukat jelzi. Végül, a kulturális metaforák a közösség tagjai számára ismertek, míg az azon kívüliek számára nehezebben értelmezhetők. Ezek a tulajdonságok a családi hasonlóság elve szerint fogják össze a kulturális metafora kategóriáját.

1.3. A magyar népdalok kulturális kontextusa. Népi kultúrán azt a kollektív tudást értjük, amelyet a paraszti közösségek az évszázadok során generációról generációra hagyományoztak át (KATONA 1998). Bár a kulturális hagyomány elsősorban az ünnepekhez kapcsolódó tartalmakat helyezi előtérbe, a rejtett „mindennapi tények” a közösségi tudás legstabilabb elemei. Ezek legfontosabbjai HOPPÁL (1982: 333-336) szerint a gesztusok, a magatartás, a viselkedési módok, az erkölcs, az érintkezési szabályok, a tér- és időhasználat, avagy a hiedelmek.

A népdalok elsősorban a parasztság érzelmeit jelenítik meg, ezen belül föként a szerelem témájához kapcsolódva, de gyakran jelenik meg bennük a honvágy, a katonaélet vagy a bujdosóélet reflexiói, avagy a haláltól való félelem. A személyes üzenettel szemben a természeti jelenetek sematizáltsága a közösségi jelleget jelzi. A népdalok variánsokban éltek, amelyekről a közösségivé válás folyamatában az alkalmi/egyéni jegyek letörlődnek (KATONA 1998: 357). Hagyományosan a népdalokat közösségben adták elö, amely közvetlenül és aktívan részt vett a diskurzus alakításában, ahol a sematikus reprezentáció lehetőséget teremtett az adott helyzetnek megfelelö adaptációra (KATONA 1998: 24).

Bár a folklorisztikában a természeti képet régóta a magyar népdal jellemzöjének tartották (KATONA 1998; LÜKÖ 1942/2002; ORTUTAY 1975), a bennük rejlö konceptualizációkról keveset tudni. Az eddigi kutatások elsősorban motívum-alapú osztályozásra (KÜLLÖS 1976; MONA 1959) és bizonyos jelentésmintázatok kimutatására irányultak stilisztikai megközelítésben (mint például a párhuzamosság, az ismétlés, az ellentét, a kicsinyítés vagy a nagyítás, vö. KATONA 2002). A szövegkezdő természeti jelenet funkcióját a rákövetkező érzelmi üzenet megalapozásaként, metaforikus „előrevetítőjeként” definiálták (MNL. 5: 271). A folklorisztika vizsgálatai szerint a természeti jelenetek kettős hatás eredményeként jelentek meg a népdalokban: részben a középkori vallási irodalom és szekuláris költészet hatá- 
sára, részben azonban a jóval azelőtti időkre vezethetők vissza (KATONA 2002). A természeti képek jelentőségét jelzi, hogy a vizsgált korpuszon belül (ORTUTAYKATONA szerk. 1975) a szerelmi dalokban, amely a legterjedelmesebb tematikus csoport, 445 dalból 319-ben (72\%) található természeti jelenet.

A konstruálás egy esemény/jelenet feldolgozó (elemző) megértése és fogalmi megalkotása valamilyen módon, több lehetséges módozat közül (TOLCSVAI NAGY 2013: 129; LANGACKER 2008: 43). A természeti képek konstruálási formái különbözőek: az érzelmeket eltérő kidolgozottságú jelenetekben viszik színre, amelyekben a cselekmények, a résztvevők és viszonyaik metaforikus jelentéssel bírnak. Többségük összetett, számos metaforát és képi sémát jelenít meg egyszerre. A korpuszvezérelt vizsgálat tapasztalatai szerint csupán az esetek kis hányadában segíti az értelmezést a párhuzamos képszerkezet, amely a természeti és az emocionális rész szemantikai és grammatikai párhuzamos megfeleltetéseit jelenti. Ezzel szemben például a szövegkezdő lehorgonyzatlan nominális szerkezetek kevés támpontot adnak a természeti jelenetek fölfejtéséhez (BARANYINÉ KóCZY 2014b, 2018).

1.4. A SZEMÉRMESSÉG mint kulturális séma. A SZEMÉRMESSÉG kulturális sémán azt az attitüdöt értem, amely a paraszti közösségekben az érzelmekről, személyes ügyekről való megnyilatkozást vezérelte. Ez a visszafogottság, tartózkodás a népdalok nyelvi reprezentációiban mind a metaforikus megjelenítés által (BARANYINÉ KÓCZY 2011a, 2011c, é. n.), mind pedig bizonyos konstruálási mintázatokban felfedezhető (BARANYINÉ KÓCZY 2011b, 2015, 2016). Hasonló jelenségre használja SzELID a csángó népdalok kapcsán a szerelem tabutémáinak metaforikus megjelenítésére a „fedőtörténet” terminust (SzELID 2007: 76). A kulturális sémát társadalmi, kulturális és gazdasági hatások együttese hozta létre, de elsősorban a paraszti erkölcsön alapult, amely az érzelemkifejezés és a házasság terén meghatározta az adekvát viselkedési normákat. A paraszti közösségek életét a korábbi generációktól hagyományozott szokások (BóDÁn 2008: 316), a keresztény egyházak tanítása, a világi hatóságok ténykedése és jobbágyság feudalizmuskori szigorú létfeltételei alakították ki (NAGY 1989: 225-249). Az egyes falvak zárt társadalmi egységekként müködtek, ahol a közösség határozott arról, mit tart erkölcstelennek, s a közösség is ítélkezett és büntetett ennek megfelelően (TOMORI 2004: 196).

A házasság és a házasulandó felek kiválasztása a falusi szokásrendszerben családi ügy volt, a legidősebb férfi, a gazda döntése (BELL 1985: 60-61). A parasztságon belül a földalapú vagyoni helyzet nagy társadalmi különbségeket teremtett, és ez alapvetően meghatározta egy házasulandó fiatal potenciális jelöltjeinek a körét (BELL 1985: 29). A közösségi elvárás szerint azonos vagyoni helyzetü fiatalok házasodtak, s ez azzal a következménnyel járt, hogy a vonzalom gyakran nem játszott szerepet a házasságkötés mérlegelésénél.

A házassággal kapcsolatban és általában a paraszti erkölcsben központi téma volt a szexualitás. A lányok szüzességének a megörzése a hozományuk legfő́bb részét képezte; az ezzel kapcsolatos kifejezések, mint a visszavehetetlen kincs, egyetlen vagyon, legnagyobb bücsü, legfóbb hozomány mind ezt támasztják alá (BÓDÁN 2008: 321). Ezzel szemben a legények elvárt viselkedési mintáiban a sze- 
relmi sikerek is szerepeltek (JÁVOR 2000: 618-622, 660). A paraszti erkölcs, a férfi-női szerepek és a házassággal kapcsolatos szokások következtében az érzelmek kinyilvánítása nem volt elfogadott a közösségekben; ezt jelöli a népdalok konstruálási jellemzőiben kifejezett SZEMÉRMESSÉG-séma.

1.5. Vizsgált korpusz és módszer. A tanulmányban szereplő népdalok a szövegvizsgálat céljára készült, a népdalokról reprezentatív képet adó Magyar népdalok címü korpuszból származnak, jelölve a tematikus csoportot és az azon belüli sorszámot (ORTUTAY-KATONA szerk. 1975). A korpusz közel 2500 szöveget tartalmaz 47 tematikus csoportra bontva; ez ,egyben a történelmi, földrajzi, etnikai kapcsolatok teljességét adja" (ORTUTAY 1975: 7). A lírai népdalok 13 tematikus csoportban találhatók meg, melyek: párosítók, fonódalok, szerelmi dalok, átokdalok, keservesek, bujdosók, vándordalok, '48-as dalok, katonadalok, pásztordalok, betyárdalok, rabénekek és halászdalok.

2. A FOLYÓ mint kulturális konceptualizáció. A folyó gyakori konceptualizáció a népdalok természeti jeleneteiben; nyelvi reprezentációik legtöbbször tulajdonnevek, ritkábban köznevek. A folyók nem mindig metaforikus értelemben szerepelnek, és a legnagyobb variabilitást a népdalok központi csoportjaként is funkcionáló szerelmi népdalokban mutatják. A folyók tehát a korpuszban természeti jelenetet tartalmazó szerelmi dalok 18\%-ában szerepelnek, míg összehasonlításképpen az ERDÖ ugyanennek a szövegcsoportnak a 9\%-ában jelenik meg (BARANYINÉ KÓCZY 2011b).

2.1. Az ÉRZELEM FOLYÓVÍZ kulturális metafora. A természeti jelenetekben a folyók számos különböző tulajdonsága a figyelem előterébe kerül. A konceptualizációk egy nagyon általános kulturális metaforát rejtenek, amely az ÉRZELEM FOLYÓVÍZ fogalmi metaforával fejezhető ki. Az ÉRZELEM FOLYÓvíz kulturális metafora AZ ÉRZELEM EGY TARTÁLYBAN LÉVÖ FOLYADÉK fogalmi metaforához kapcsolható leginkább (KÖVECSES 2000: 26; vö. a DÜH kapcsán KÖVECSES 2005b: 170-171), de olyan képi sémákban jelenik meg, amelyekben erőteljesen tetten érhető a folyókról szerzett perceptuális tapasztalat dominanciája - szemben a TARTÁLY-séma általános tapasztalatával. Továbbá, kérdéses, hogy a folyómeder konceptualizálható-e tartályként, hiszen jelentős különbség közöttük az előbbi esetében a folyadék állandó mozgása, míg az utóbbiban a folyadék nyugvó állapotban statikus (BARANYINÉ KÓCZY é. n.).

A paraszti közösségek viszonya a folyókhoz sokrétü és ellentmondásos volt: „A néphitben [...] a Tisza vizének mint víznek tisztító, gyógyító, bajelhárító szerepet tulajdonítanak. A tavaszi népszokásokban különös jelentősége van a víznek. Tisztító erejében sokan még ma is hisznek, de már nem őrzik a hagyományokat, nem végzik el a rituális cselekményt a meghatározott naptári ünnepeken. A Tisza a közmondásokban, a néphitben is megjelenik. A folyóvíz az állandó tisztulás, újulás jelképe. Jelentősége a tisztasággal, az egészséggel szorosan összefügg. A népszokásokban gyakran átmenetet, illetve ellentétet is képvisel" (NAGY ABONYI 2015: 109-110).

Miközben a Tiszát a népi életmód meghatározó elemeként ragaszkodás, tisztelet övezte, addig egyidejűleg számoltak romboló, mágikus és tisztító erejével is. „Folyóként a Tiszának összekötő szerepe van. Összeköti a népeket, meghatározza 
az ember életmódját, élelmet ad, foglalkozást biztosít, élteti a hagyományvilágot és a népköltészetet. A Tiszát a folyópart lakói tisztelik, és akkor sem lázongnak, amikor elnyeléssel fenyegeti hajlékukat. [...] Bár ismerte a folyó romboló erejét, mégis a folyóvíz közelében telepedett le, mivel a víz biológiai jelentőségét, szépségét a veszélynél többre becsülte, s hitt mágikus, természetfeletti erejében" (NAGY ABONYI 2000).

A folyók tapasztalata a térbeli-strukturális (statikus) jellemzőikből és a folyóvíz (dinamikus) változékonyságából származott. A képi sémák gyakran komplex módon, több metaforát vegyítve jelenítik meg a folyókat, így például alább:

(1) Kiöntött a Tisza vize; Szöke kislány fürdik benne.

Én is megfürödtem benne, Rám is ragadt a szerelme. (Szerelmi dalok: 85)

A legény és a lány ugyanabban a tevékenységben (fürdés) vesznek részt, ezáltal azonos érzelmi állapotba kerülnek (szerelem). A fürdés és a szerelem között tehát ok-okozati összefüggés van, melynek alapja a szerelem „ragadóssága” a vízen keresztül. Az egyik metafora tehát A SZERELEMBE ESÉS FÜRDÉS A FOLYÓVÍZBEN; ebben a konceptualizációban a SZERELEM egy külső erőhatásként jelenik meg. Ezzel szemben az első sorban egy másik metafora is megfigyelhető, A TÚLÁRADÓ ÉRZELEM A FOLYÓ ÁRADÁSA. A két metafora más fogalmi metaforából eredeztethető: AZ ÉRZELEM TARTÁLYBAN LÉVŐ FOLYADÉK azt implikálja, hogy a FOLYÓMEDER a TARTÁLY, azaz a szerelmes ember, a FÜRDÉS-metafora pedig a SZERELEM BETEGSÉG metaforát hívja elő (KÖVECSES 2005b: 47). Egy további fogalmi metafora a természeti jelenetben A SZERELEM EGYSÉG, amelyet a Tisza egyesítő szerepe hoz létre.

Egy másik példa AZ ÉRZELEM FOLYÓvíZ metaforára a (2)-es népdal. Az áradás itt nem metaforikusan is értelmezhetö, mint a tavaszi környezet, az állatok párválasztási időszakának előidézése. AZ ÉRZELEM FOLYÓvíZ metafora intertextuális alapú ismeretében azonban az ÁRADÁS ÉRZELMI ÁRADATot fejez ki, az udvarlás érzelmi motivációját.

(2) Tavaszi szél vizet áraszt, virágom, virágom; Tavaszi szél vizet áraszt, virágom, virágom. Minden madár társat választ, virágom, virágom; Minden madár társat választ, virágom, virágom. (Szerelmi dalok: 1)

Az ÉRZELEM FOLYÓVÍZ metafora változatos kontextusokban reprezentálódik. Bizonyos esetekben homályos értelmü, mint azt a (3)-as szöveg is bizonyítja. Látható az a népdalokra jellemző tulajdonság is, hogy a térbeli irányultság a metaforikus jelentés egyik fö aspektusa. 
(3) Tisza szélin egy nagy nyárfa tüvibe Barna leány ül a legény ölibe. Legény nézi folyó vize nagy habját, Leány nézi az ragyogós csillagját. (Szerelmi dalok: 216)

A szerelmi jelenet térviszonyait alapvetően a Tisza, a part és a nyárfa határozza meg. Ebben a lehorgonyzatlanul „lebego”” képben az indirekt kifejezésmód része a folyó vize kifejezés kettős értelmezhetősége: jelentheti birtokos szerkezetként a „folyóvizet”, a folyó közelségére utalva, vagy jelzős szerkezetként a „legény folyó vizét", más szóval a szexuális aktust eredményét. Mindkét értelmezés érvényes a kontextusban. A kettős értelmezés lehetősége a természeti megjelenítéshez hasonlóan az indirekt kifejezésmód és a SZEMÉRMESSÉG séma része. A jelenetet átható diszharmónia forrása a legény és a leány tekintetének ellentétes iránya és eltérő hatóköre. A lány felfelé tekint a távoli csillagjára, metaforikusan megjelenítve a reményét a szerelmi kapcsolat jövöjében. A legény ezzel szemben lefelé és közelre tekint, a szexuális aktus közvetlen eredményére fókuszál. Ez a kettősség a házasság előtti szexuális aktus eltérő perspektívából történő értelmezését képezi le a térbeli viszonyok metaforizációjában. A szexuális aktus a paraszti erkölcs szabályainak megszegését jelenti, azonban ez másképpen érvényes a női és férfi szerepsémák szempontjából. BóDÁN kiemeli, hogy a szigorú erkölcsi princípiumok dacára voltak lányok, akik tudatosan kerültek intim kapcsolatba egy módos legénynyel, reménykedve abban, hogy így házasságra kényszeríthetik. Gyakran azonban így sem sikerült megszerezniük a legény családjának beleegyezését (BóDÁN 2008: 321). A (3)-as népdal a szerző értelmezése szerint úgy értelmezhető, hogy a lány házassági reményével szemben a legény figyelme csupán az aktusra irányul.

Összegzésként, a folyóvíz változékonysága mint forrástartomány számos szerelemmel kapcsolatos érzelmi helyzet közvetítésére szolgál a népdalokban, amelyek végső soron a SZERELEM FOLYÓvíZ kulturális metaforára vezethetők vissza. A FOLYÓvíz térbeli jellemzői dominánsak, például a térbeli kiterjedés vagy a mozgás minősége és iránya. A következő elemzések azt támasztják alá, hogy a folyók jellemzői nem egyetlen metaforikus funkciót tölthetnek be, hanem különböző kontextusokban más és más jelentést kaphatnak.

2.2. Az ÁRADÁS, a FAGYÁS és a ZAVAROS VÍZ forrástartományai. Az (1)-es és a (2)-es népdalokban a folyóvíz a TÚLÁRADÓ érzelem állapotát jelenítette meg. Más népdalokban az ÁRADÁS másképpen jelenik meg, a konceptualizáló vágyát fejezve ki.

(4) Ha folyóvíz vónék, Bánatot nem tudnék;

Hegyek, vögyek között

Zengedezve járnék.

Ahol kitírülnék, Porondot hajtanék; 
Kaszálórétekbe

Virágot növelnék.

(Szerelmi dalok: 179)

A (4)-es népdal ble $\mathrm{ndk}$ é $\mathrm{n} t$ is értelmezhető (FAUCONNIER-TURNER 2002: 255), amelyben két bemeneti tér integrálódik: az egyik a „folyó” és annak tapasztalati elemei, a másik pedig az „én”, a konceptualizáló, aki szeretné az érzelmeit szabadon engedni. Az „én” és a „folyó” közös integrált terét a konceptualizáló érzelmi állapota és a folyó ereje, szabad folyása határozza meg. A (4)-es népdal a FOLYÓ ellentmondásos helyzetét jeleníti meg a népi konceptualizációban: a fizikai rombolással (kitírülnék, porondot hajtanék) egyidejüleg a folyók építenek is (virágot növelnék).

A népdalban megjelenő ÁRADÁs tapasztalata ambivalens volt a magyar népi kultúrában: míg az áradás súlyos károkat okozhatott, addig az ártéri gazdálkodás az áradás következtében termékennyé vált talajt hasznosítja. A folyóvíz korlátlan mozgása a korlátoktól és gondoktól mentes érzelmi állapotot képezi le (bánatot nem tudnék, zengedezve járnék). A folyó kiáradásának konceptualizációjában a meder a fizikai korlát funkcióját tölti be, amelynek átlépése átmeneti és rendkívüli jelenség; ennek metaforikus megfelelője a népi kultúrában az a társadalmi elvárás, hogy az egyén az érzelmeit kontrollálja és megtartsa magának. Azáltal, hogy a központi téma az érzelmek elfojtása, illetve szabadon engedése (mely csak a vágyott fiktív jelenetben történik meg), a népdal a SZEMÉRMESSÉG kulturális séma prototipikus példányaként is felfogható.

Az ÁRADÁs tehát a (4)-es népdalban megjelenő konceptuális keretben rendkívüli érzelmi állapotot jelez, míg a „normális”, konvenciók szerinti állapot a mederben folyó víz képe. Alább ez a „normális” állapot kerül a figyelem előterébe, így itt érthetőbbé válik, hogy a medrében folyó víz csak színlelt nyugalmi állapot, hiszen a kifárad szó arra utal, hogy az áradás a nyugalmi állapot megőrzésében való elfáradás eredményeként következik be.

(5) Úgy nyugszik a szívem gyászba,

Mint a Maros az árkába,

De még az is, ha kifárad,

A mezökre ki-kiárad.

(Keservesek: 7)

Az (5) népdalban a nyugszik ellentéteként jelenik meg a kiárad, valamint okokozati viszonyban vannak a kifárad $\Rightarrow$ kiárad konceptusok. Eszerint a medrében nyugvó folyó folyamatos erőfeszítést tesz arra, hogy az árkában maradjon, ezért belső konfliktust képez le. Az ÁRADÁs a gyászoló „én” nézőpontjából tekintve pozitív irányú változást konceptualizál: A MEGKÖNNYEBBÜLÉS ÁRADÁS.

A folyóvízzel kapcsolatos másik alapvető tapasztalat a telet idéző befagyás, amelynek egyrészt hőmérsékleti (hideg), másrészt mozgásbeli (mozdulatlan) relevanciái vannak. A BEFAGYOTT FOLYÓVÍZ az ÉRZELEM MELEGSÉG/HIDEGSÉG metaforához köthető, ahol az érzelem megléte melegséget, míg hiánya/elmúlása hideg 
vizet jelez (KöVECSES 2000: 39), ez a népdalokban negatív konceptualizáció, szerelmi kontextusban MÚLÓ SZERELMet fejez ki (6).

(6) Mi dolog az, hogy a Tisza befagyott?

Hogy engemet az én rózsám elhagyott?

Szokása a Tiszának a befagyás.

A legénynek a szeretö-elhagyás.

(Szerelmi dalok: 347)

Létezik azonban egy teljesen más konceptualizációja is a BEFAGYOTT FOLYÓVÍZnek:

(7) A nyári folyóvíz

Télre megaluszik,

De az én bús szivem

Soha meg nem nyugszik.

(Szerelmi dalok: 318)

A fagyás fizikai változásának metaforikus ellentéte a zavaros víz, amely háborgó, nyugtalan érzelmet jelent. A konceptualizáló implicit vágya a megkönnyebbülés, az érzelmi stabilitás elnyerése. Érdekes módon tehát itt a FAGYÁs vágyott állapot, pozitív konceptualizáció: a befagyott folyóvíz képének felidézése a folyók természetes módon bekövetkező változásának szembeállítása a megnyilatkozó soha meg nem szünő bánatával: AZ ÉRZELMI NYUGALOM BEFAGYOTT FOLYÓVÍZ. A BEFAGYOTT VÍZ tehát két merőben eltérő (pozitív és negatív) konceptualizáció forrása, mindkettőben az évente bekövetkező kiszámítható jelenség tapasztalata alapvető. A két eltérő konceptualizáció a különböző képi sémákban megjelenő funkciók miatt lehetséges (vö. BARANYINÉ KÓCZY é. n.).

A folyóvíz harmadik jellemző állapota a zavaros víz, amely az áradás velejárója. Ekkor a vizet kaotikus mozgás jellemzi, és a felkavart iszaptól sárgássá, „piszkossá” válik (innen az elnevezés: szőke Tisza).

(8) Zavaros a Maros, Nem akar higgadni.

Hej, haragos a babám,

Nem akar békélni.

(Szerelmi dalok: 375)

Az 1-2. és a 3-4. sor állításai a folyóról és a kapcsolatról a szintaktikai párhuzam miatt könnyen hozzáférhetővé teszik a megfeleltetést. A ZAVAROS FOLYÓvíz a szerelmi társ DÜHét reprezentálja, míg higgadása a kapcsolati konfliktus megoldását jelentené. A zavaros víz temporális jelenség, így egyben azt is implikálja, hogy a megnyilatkozó reménykedik a közeli kiengesztelődésben. Ez a konceptualizáció jelenik meg alább is: 
(9) Szöke vize a zavaros Tiszának,

Mondd meg annak a szép barna kisjánnak,

Hogy az egész Tisza vize mentiben,

Nincsen ollyan barna kisján sehol sem!

(Szerelmi dalok: 270)

Az első sorban a rövid utalás a Tiszára nem tartalmaz állítást, ezáltal a metaforikus kép kapcsolata a rákövetkező résszel nehezen értelmezhető. A nem metaforikus rész leírja, hogy a konceptualizáló egy közvetítőt kér meg, adja át a csodálatát a szerelme tárgyát képező lánynak. A jelenet azt implikálja, hogy a megnyilatkozó és a lány távol helyezkednek el egymástól (erre utal az annak távolra mutató deixis, vö. AZ ÉRZELMI KAPCSOLAT KÉT ENTITÁS TÁVOLSÁGA, KÖVECSES 2000: 92), valamint a beszélő bátortalan ahhoz, hogy direkt módon fejezze ki az érzelmeit. Mindez negatív helyzetet feltételez, amely hasonló a (8)-as dalban elemzett kulturális metaforához: A DÜH ZAVAROS FOLYÓvíz. A Tisza jelzői: szöke és zavaros, ezek a lány szépségére és haragjára utalnak, hiszen ahogy a reprezentációban a szőkének minősítés ki van emelve a zavarossághoz képest, úgy a lány szépsége nagyobb hatású, mint a haragja, így a Tisza reprezentációja végső soron a kapcsolat kettős minőségét tükrözi.

2.3. A LÓITATÁS A FOLYÓBAN képi séma. Az (1)-(9)-es népdalok elemzéseiből látható, hogy a FOLYÓhoz füződő különböző konceptualizációk nem alkotnak olyan megfeleltetéseken alapuló rendszert, amellyel bármely természeti jelenetet értelmezni lehetne az adott kontextustól függetlenül. Vannak azonban olyan metaforák, melyek egymással szorosabban összefüggnek egy közös fogalmi keret, képi séma által. A korábbiakban elemzett népdalok közül több is a LÓ ITATÁSA A FOLYÓBAN képi séma kidolgozásaként magyarázható.

Az IVÁS és az ITATÁS (állat itatása) konvencionális metaforikus tartományok a népdalokban, az ÉRZELEM SZOMJÚSÁG fogalmi metaforához kapcsolódnak (KÖVECSES 2000: 78). Figyeljük meg a (10)-es és a (11)-es népdalt!

(10) A szegedi tábla búza

Véggel van az országútra.

Még a fejét ki sem hányta,

Már két galamb körüljárta.

Bárcsak én azt megfoghatnám,

Kalickába bezárhatnám!

Tiszta búzával tartanám,

Folyóvizzel itatgatnám;

Kedves galambomnak adnám.

(Szerelmi dalok: 14)

(11) Gerlice a búzát

A párjának hordja,

Mint a lyány a legényt, 
Csókjában itatja.

(Szerelmi dalok: 119/4)

A (10)-es népdalban a FOLYÓVÍZIVÁS JÓLÉT HELYETT metonímia szerelmi kontextusban figyelhető meg: a galamb birtoklása és jóltartása azt reprezentálja, ahogy a férfi konceptualizáló kíván gondoskodni a szerelmi társáról. A (11)-es népdalban nyilvánvalóvá válik, hogy az IVÁS valójában CSÓKot jelent: a búza ételnek, míg a csók italnak felel meg. A csókjában itatja kifejezés, tágabb összefüggésben a fizikai támaszon túl az érzelmi gondoskodást is jelentheti.

A LÓ ITATÁSA a SZEXUÁLIS AKTUS metaforikus reprezentációja a népdalokban. A forrástartomány feltehetőleg a magyarok lótartási hagyományaira vezethető vissza (PALÁDI-KOVÁCS 2001), de annyi bizonyos, hogy a népi társadalom részét képező pásztorok, juhászok és csikósok lovaira utal. A pásztorkodással mint uralkodó állattenyésztési formával sokszor együtt járt a télen-nyáron át tartó legeltetés, amely azt jelentette, hogy a pásztorok életük nagy részét a közösségtől távol, magányosan töltötték. Ezzel magyarázható a paraszti normákkal, erkölccsel szembeni „kívülálló" magatartásuk, amely a népdalokban tetten érhető (MNL. 4: 209-210).

A ló itatásának egyik akadálya lehet a befagyott víz:

(12) Nincsen hideg, mégis befagyott a tó,

Kibül iszik babám lova, a fakó.

Ergye, pajtás, vágd föl néki a jeget,

Hadd igyék a babám lova öleget!

(Betyárdalok: 19/1)

A (12)-es népdalban az első sor és a babám lova kifejezés utal a metaforikus értelmezés lehetőségére. Eszerint a megfeleltetések a következők:

\author{
A LEGÉNY $\mid$ A LÓ \\ A LÁNY A TÓ \\ A LÁNY ELLENÁLLÁSA A JÉG \\ A LÁNY ELLENÁLLÁSÁNAK MEGTÖRÉSE A JÉG FÖLVÁGÁSA \\ SZEXUÁLIS AKTUS $\mid$ A LÓ ITATÁSA
}

A tó funkciója hasonló a folyóéhoz; ismét a víz minősége hiúsítja meg a ló itatását, amelynek alapja a MÚLÓ SZERELEM/ELUTASÍTÁS BEFAGYOTT VÍZ metafora.

Ugyanez a séma jelenik meg (13)-ban is, itt azonban a víz minősége gátolja meg az itatást.

(13) Zavaros a Tisza vize, nem tiszta.

Ráhajtottam kis pej lovam, nem issza.

Ha nem issza, ráhajtom a széles Dunára,

Mégsem leszek senki megunt babája.

(Szerelmi dalok: 360) 
A (13)-as népdal a LÓ ITATÁSA A FOLYÓBAN képi sémát részletesen dolgozza ki: a ló itatásának gátlója a zavaros és piszkos víz. A zavaros víz itt is a lány érzelmi állapotát jeleníti meg, ahogyan korábban A DÜH ZAVAROS FOLYÓVÍZ metafora esetében. A 4. sor explicitté teszi az érzelmek és az itatás közötti megfeleltetést: az által, hogy nem tudja megitatni a lovát (mivel a szerelme elutasítja) a lovas elhanyagolva érzi magát, így más lánnyal keres intim kapcsolatot. Hasonló képi sémát fejt ki a (14)-es népdal.

(14) Letörött a kutam gémje, Hun itatok mán estvére?

Kinyes az én lovam szája,

Nem szokott a más kútjára.

Nem szokott a más kútjára...

Belehajtom a Tiszába;

A Tiszának közepibe,

Onnan a másik szílire.

(Szerelmi dalok: 11)

A népdal szerint a beszélő nem tudja megitatni a lovát a saját kútjából, mivel az nem müködik: a törött gémmel nem tud vizet meríteni belőle. Ennek a metaforikus jelentése a (12)-es és (13)-as népdalok konceptualizációjának tanulsága szerint szerelmi kontextusban az, hogy nem tudja kielégíteni a szexuális vágyát, mivel a lány visszautasítja. A metaforikus jelentést a napszak (este) és a „kényes” szájú ló jelzi. A lány visszautasítására válaszul a lovas úgy dönt, a Tisza felé vezeti a lovát, mivel ott bőven talál vizet az itatáshoz; azaz metaforikus értelemben más lány után néz, hogy vágyát kielégítse. A ló áthajtása a túlpartra a szexuális aktust jelenti (1. 2.5.-ben az ÁTKELÉS képi sémát). A képi séma főbb megfeleltetései a következők:

\begin{tabular}{r|l} 
A LEGÉNY & A LÓ \\
A LÁNY & A KÚT \\
SZEXUÁLIS AKTUS & A LÓ ITATÁSA \\
& ÁTKELÉS A FOLYÓ TÚLSÓ OLDALÁRA \\
A LÁNY ELUTASÍTÁSA & A TÖRÖTT GÉM \\
LEHETŐSÉGEK A SZEXUÁLIS AKTUSRA & A VÍZ MENNYISÉGE A FOLYÓBAN
\end{tabular}

A LÓ ITATÁSA A FOLYÓBAN képi séma kidolgozott jeleneteiben A DÜH ZAVAROS FOLYÓVÍZ és A MÚLÓ SZERELEM BEFAGYOTT VÍZ kulturális metaforák figyelhetők meg, amelyek megmagyarázzák a reprezentált szerelmi kapcsolat negatív aspektusát. A kérdés az, hogy a két kulturális metafora hátterében is implicit módon müködik-e a képi séma. Nyelvi bizonyíték nincsen rá, azonban a népdalok eddig elemzett példái is jól demonstrálják a konceptualizációk elrendeződésében a he terogén dis ztribúci ó elvét. Az egyes népdalok természeti jelenetei, pontosabban a bennük megjelenő metaforák néhány közös jegyük alapján kapcso- 
lódnak egymáshoz. Így lehetséges, hogy a szemantikai kapcsolat az első két sor között (6)-ban (Mi dolog az, hogy a Tisza befagyott? / Hogy engemet az én rózsám elhagyott?) az ITATÁs sémán alapul. A szerelmi kontextusban kifejezett negatív élmények (befagyott víz, zavaros víz) a parasztság hétköznapi életének tapasztalataiban gyökereznek. A (12)-(14)-es népdalok arra is rámutatnak, hogy esetenként a népdalokban semmilyen vagy esetleg minimális utalás található a szexuális kontextusban való értelmezés lehetőségére. Ennek egyik oka a SZEMÉRMESSÉG séma szerint a szexuális tartalom indirekt kifejezése (pontosabban a közvetlen utalás elkerülése). A másik ok az, hogy a paraszti közösségben mindenki számára ismertek voltak a kulturális metaforák, így azok értelmezéséhez nem volt szükség a megfeleltetés kifejtése.

(Folytatjuk.)

BARANYINÉ KÓCZY JUDIT Széchenyi István Egyetem 